\title{
ІСТОРІЯ ТА ПЕРСПЕКТИВИ РОЗВИТКУ ННІ МЕДСЕСТРИНСТВА ТЕРНОПІЛЬСЬКОГО ДЕРЖАВНОГО МЕДИЧНОГО УНІВЕРСИТЕТУ IМЕНІ І. Я. ГОРБАЧЕВСЬКОГО
}

\author{
С. О. Ястремська, І. Я. Господарський, О. С. Усинська, Н. І. Рега, \\ С. О. Коноваленко, В.С. Городецький \\ ННІмедсестринства
}

\section{HISTORY AND PROSPECTS OF DEVELOPMENT OF INSTITUTE OF NURSING, OF TERNOPIL STATE MEDICAL UNIVERSITY BY I. YA. HORBACHEVSKY}

\author{
S. O. Yastremska, I. Ya. Hospodarskyi, O. S. Usynska, N. I. Reha, S. O. Konovalenko, \\ V. Ye. Horodetskyi
}

Institute of Nursing

\begin{abstract}
Стаття присвячена історії становлення та розвитку ННІ медсестринства у складі Тернопільського державного медичного університету імені І. Я. Горбачевського. За декілька років ННІ медсестринства став одним із передових закладів медсестринської освіти в Україні. Сьогодні тут проводиться підготовка бакалаврів та магістрів медсестринства, створена та успішно працює програма дистанційної освіти, функціонує Міжнародна медсестринська школа. У найближчих планах ННІ - удосконалення програми дистанційного навчання з метою залучення більшої кількості студентів.
\end{abstract}

The article is dedicated to the history of development of Institute of nursing as a part of Ternopil State Medical University. For the several last years Institute of Nursing became the one of the most advanced institution of nursing education in Ukraine. Today BSN and MSN programs work here, Distance learning program is created and works successfully, International nursing school is also functioning. The nearest plans of Institute of nursing are to improve the distance learning program and engage even more international and Ukrainian students to study here.

Вступ. Одним із пріоритетних завдань Тернопільського державного медичного університету імені І. Я. Горбачевського є подолання стереотипу у підготовці та ставленні до медичних сестер як до виконавців ролі помічника лікаря у ході лікувально-діагностичного процесу, оскільки сучасне життя заставляє підняти рівень вітчизняної медсестринської справи до вимог світових стандартів.

Окремим підрозділом, що поєднує теоретичну i практичну підготовку середнього медичного персоналу, в ТДМУ став ННІ медсестринства.

Основна частина. Беручи до уваги те, що підготовка медичних сестер - молодших спеціалістів в Україні має багатолітній досвід, в ННІ медсестринства більше уваги приділяється підготовці медичних сестер кваліфікаційного рівня “бакалавр" та “магістр”, які безпосередньо будуть брати участь у навчанні та підготовці основної маси медичних сестер, а також керувати ними у практичній роботі у якості організаторів та менеджерів охорони здоров'я.

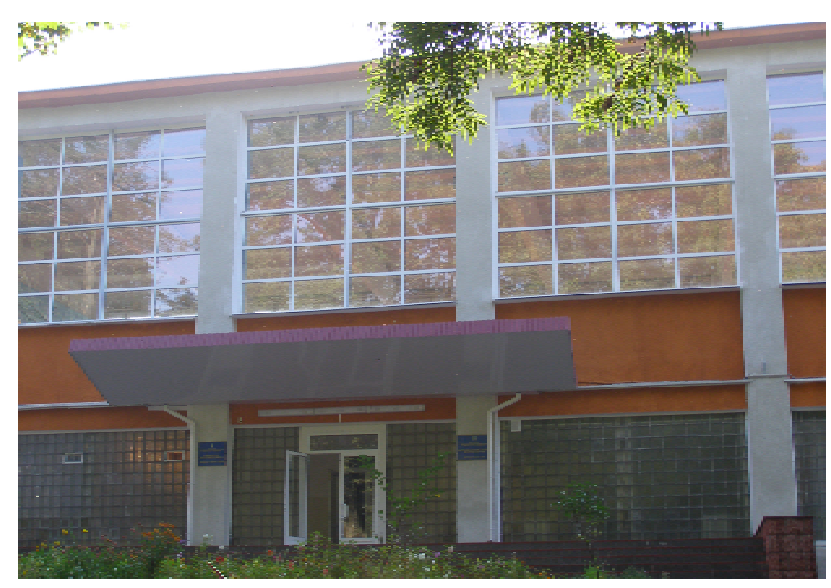

Фото 1. Новий навчальний корпус ННІ медсестринства на вул. Коцюбинського, 3 .

Фактично з впровадженням бакалаврату у 1995 році Інститут медсестринства почав готувати медсестер-менеджерів, які можуть і повинні працювати як самостійні професіонали, співпрацювати з лікарем, а не просто допомагати йому.

(ㄱ С. О. Ястремська, І. Я. Господарський, О. С. Усинська та ін. 
Сьогодні ННІ медсестринства здійснює підготовку медичних сестер за I рівнем акредитації, медичних сестер-бакалаврів та лаборантів-бакалаврів - за II рівнем акредитації та медсестер-магістрів за IV рівнем акредитації серед вітчизняних та іноземних громадян. В інституті навчається 334 студенти. Навчання проводиться за денною та дистанційною формами.

Для того щоб медичні сестри змогли брати участь на рівних в освітянських бліц-програмах, майстер-класах, користуватися можливостями дистанційної освіти, вже 3 самого початку проводилась робота з успішного засвоєння дисциплін навчального процесу, пов'язаних 3 роботою на комп'ютерах, оволодіння майбутніми медсестрами сучасними інформаційними технологіями. Це вимагає відповідного забезпечення та підготовки високопрофесійного викладацького складу.

Оновлений професорсько-викладацький склад інституту медсестринства в період з 2007 по 2012 роки складався із команди молодих, високоосвічених людей (проф. І. Я. Господарського, проф. Ю. І. Сливки, проф. О. М. Кота, доц. С. О. Ястремської, доц. О. С. Усинської, доц. Б. А. Локая, доц. Н. Я. Давидович, доц. Н. І. Реги, доц. О. І. Зарудної, асистентів: С. О. Коноваленко, В. В. Максимової, В. Є. Городецького, О. Л. Сидоренко, Л. П. Мазур, О. М. Лепявко-Креховської, І. В. Яворської, Н. В. Петренко, Н. В. Ревчук, І. В. Корди, старших лаборантів О. В. Корнецького, О. М. Намісняк і Т. Ю. Рибалки.). Усі викладачі і навіть лаборанти інституту (О. М. Прокопів, О. В. Корнецький) відмінно володіють англійською мовою. Увесь колектив проходив стажування у різних університетах США та Канади.

Сьогодні колектив ННІ медсестринства очолює директор доц. С. О. Ястремська. ІЇ̈ заступником та одночасно директором Центру дистанційної освіти $€$ доц. О. С. Усинська. У складі ННІ медсестринства $€$ кафедра клінічної імунології, алергології та загального догляду за хворими під керівництвом д-ра мед. наук, проф. І. Я. Господарського.

Обов'язки заступника директора з організації проведення практики студентами виконує асистент кафедри клінічної імунології, алергології та загального догляду за хворими В. В. Максимова.

Матеріально-технічна база ННІ повністю оновлена та оснащена найсучаснішими навчальними муляжами, манекенами та тренажерами. Комп'ютерна лабораторія $є$ чи не найкращою в університеті. Прекрасна бібліотека підручників 3 медсестринства американських та канадських видань $€$ важливим джерелом для підготовки до занять для студентів та викладачів.

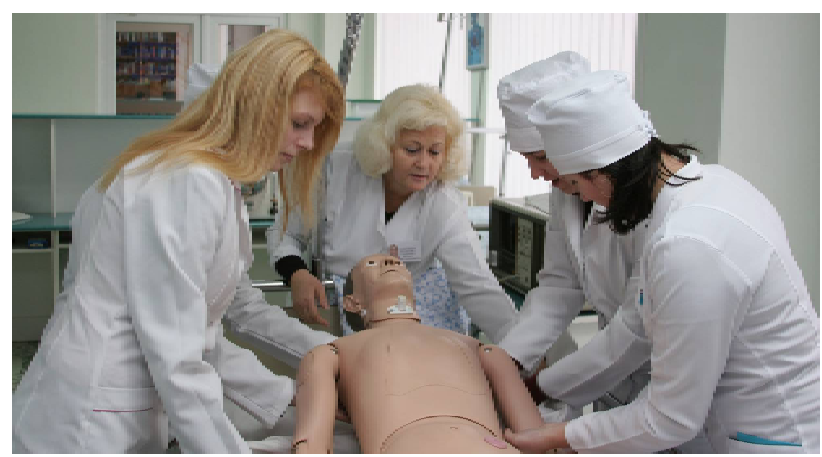

Фото 2. Асистент В. В. Максимова із студентами в лабораторії практичних навичок.

Ще задовго до реорганізації ТДМУ здійснював активну міжнародну співпрацю з університетами США, Канади та Європи з питань медсестринської освіти. Ужеза рік інститут медсестринства сформував у своїй структурі нові підрозділи, такі як Американська та Міжнародні медсестринські школи. Вперше в Україні згідно з наказом МОЗ та МОН України в ТДМУ почав успішно функціонувати експериментальний освітній проект щодо підготовки фахівців з медсестринства 3 числа іноземних громадян за спеціальними навчальними планами, що грунтуються на досвіді кращих американських медсестринських шкіл.

Почавши усього 310 студентів у 2006 р., станом на 2012 рік було збільшено набір студентів у тридцять разів. В 2011-12 н. р. контингент іноземних студентів становить 286 осіб, які навчаються за денною та дистанційною формою навчання.

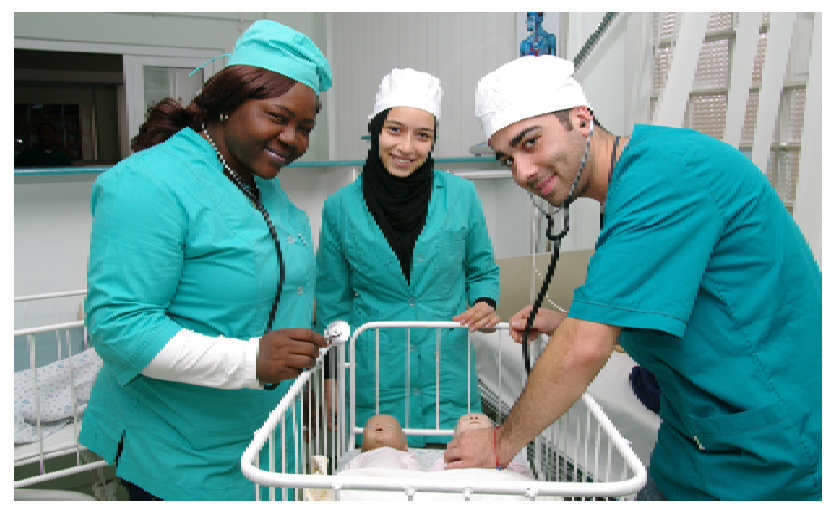

Фото 3. Вивчення медсестринських маніпуляцій студентами-іноземцями.

Зрозуміло, що мета цього проекту була і економічною - усім відома нестача медсестер у США, i саме 3 метою далі працювати там і приїжджають до нас іноземні студенти. Приваблює їх не лише англомовна програма за американськими підручниками, але i можливість продовження навчання на бакалавраті медсестринства в медсестринській школі ім. Мері Блек Університету Південної Кароліни Апстейт, 3 якою ми маємо тривалу співпрацю. 
Результатом успішної роботи зі створення освітніх стандартів стало внесення змін до Постанови Кабінету міністрів України № 507 від 24/05 1997 р. про введення в дію освітньо-кваліфікаційного рівня “магістр сестринської справи” (8.12010006 “Сестринська справа”), напряму підготовки 1101 “Медицина”. Відповідно, вперше в Україні, в Навчально-науковому інституті медсестринства Тернопільського державного медичного університету імені І. Я. Горбачевського розпочата підготовка фахівців такого рівня.

Магістри медсестринства, перший випуск яких відбувся влітку 2010 р., мають стати у центрі системи підготовки медичних сестер - молодших спеціалістів та бакалаврів, тому що розвиток профілактичної, сімейної, паліативної і страхової медицини робить ще більш необхідним дану спеціальність для практичної охорони здоров' я. Вони як медичні сестри нової формації, поряд з виконанням звичних уже функцій, повинні уміти організовувати і керувати відділеннями сестринської допомоги, хоспісами, а також бути організаторами роботи медсестринського персоналу, відділень усіх медичних, лікувальнопрофілактичних та реабілітаційних закладів.

32008 по 2012 н. р. освітньо-кваліфікаційний рівень магістра медсестринства отримали 53 особи. Це головні медсестри лікарень м. Тернополя, викладачі ТДМУ, випускники медичних коледжів, які попередньо здобули кваліфікацію бакалавра медсестринства.

Підготовка медсестер-магістрів вимагає удосконалення форм та методів навчального процесу. Частина з них у нашому університеті вже успішно вирішена після проведення великого обсягу роботи 3 інформаційного забезпечення. Так, майбутні фахівці медсестринства усіх рівнів мають доступ до сучасних інформаційних технологій. Магістранти медсестринства як майбутні викладачі добре ознайомлені 3 комп'ютерними технологіями, що у подальшій діяльності буде їм вкрай необхідно для розробки власних електронних навчальних матеріалів. Вирішувалась 1 проблема об' єктивізації оцінювання знань медсестер шляхом проведення незалежного комплексного тестового іспиту у кінці кожного семестру. Були створені умови для вивчення у ННІ медсестринства англійської мови, що стає невід'ємним атрибутом фахівця медсестринства на рівні міжнародних вимог $\mathrm{i}$ відкриває шлях для підвищення професійної підготовки та можливого працевлаштування у багатьох країнах світу. Цьому сприяють численні стажування наших викладачів і студентів за кордоном з метою вивчення системи навчання медичних сестер у США, зокрема, особливостей клінічної роботи студентів та налагодження питання щодо співпраці з Тернопільським державним медичним університетом.

Головною складовою ступеневої освіти в медицині $\epsilon$ забезпечення безперервності підготовки фахівців, а це, в свою чергу, передбачає запровадження суттєвих методологічних змін в навчанні. В сучасних умовах при різкому зростанні обсягу інформації та утрудненості перебування осіб на очному циклі одним $з$ можливих виходів у забезпеченні професійної підготовки спеціалістів є запровадження дистанційної форми навчання. Вивчивши світовий досвід роботи дистанційної форми навчання на детальному прикладі медсестринської школи Мері Блек (Південна Кароліна, США) та заручившись підтримкою Міністерства охорони здоров'я України, Тернопільський державний медичний університет імені І. Я. Горбачевського вперше в державі з 2008-2009 н. р. запровадив дану форму навчання щодо підготовки медсестер-бакалаврів.

Дистанційна форма навчання на основі новітніх інформаційних технологій дозволяє підвищити кваліфікаційний рівень мотивованої до навчання медсестри без відриву від робочого процесу, збільшити студентську аудиторію, залучивши до навчання й іноземних громадян, що в перспективі забезпечить стабільну роботу та фінансову незалежність університету, а також забезпечить викладацький склад медичних коледжів України висококваліфікованими кадрами.

У 2011 р. було здійснено перший випуск бакалаврів дистанційної форми навчання. Це 16 вітчизняних і 26 іноземних студентів.

Контингент студентів дистанційної форми навчання зі спеціальності “Сестринська справа” освітньокваліфікаційного рівня “бакалавр” у 2011-2012 н. p. становив 233 студенти (громадяни України - 44, іноземні громадяни -189 студентів).

Набирає актуальності проблема дистанційного навчання і для магістрів, яка теж започаткована у нашому університеті іє одним із напрямків суспільної інформатизації. В 2011-12 навчальному році за дистанційною формою навчаються 19 магістрів 3 медсестринства, а надалі - планується впровадження наукових ступенів і аспірантури в медсестринстві, як втілення у життя реформ в галузі медсестринської освіти МО3 України та Всеукраїнської програми розвитку медсестринства України на 2005-2010 рр., затвердженої наказом МО3 України № 585 від 08.11.2005 p.

Майже кожного року наш навчально-науковий інститут виступає ініціатором проведення потужних міжнародних конференцій з медсестринства. 
Студенти та молоді вчені ННI медсестринства беруть активну участь у міжнародних конференціях, семінарах та симпозіумах. До наукової роботи залучені як вітчизняні студенти (в 2010 році захищено 18 магістерських робіт, у 2001 - 4 магістерські роботи, у 2012 - 12 наукових робіт), так і студенти-іноземці (в 2010 - 2012 роках на конференції студентів та молодих вчених були представлені роботи бакалаврів медсестринства).

Висновок. Багато було досягнуто за 5 років існування ННІ медсестринства, але це -лише невелика частина шляху.

У подальших планах НHI медсестринства - вдосконалення роботи над існуючими програмами, щоб в майбутньому інститут могли називати не лише пер- шим, але й кращим освітнім закладом медсестринської освіти.

Планується впровадження аспірантури в медсестринстві, як втілення у життя реформ в галузі медсестринської освіти MO3 України та Всеукраїнської програми розвитку медсестринства України, затвердженої наказом МОЗ України № 585 від 08.11.2005 p.

Особлива увага сьогодні привернута до покращення та розширення проекту дистанційної освіти, який виводить Тернопільський державний медичний університет на міжнародний рівень у якості повноправного гравця. Ми сподіваємось, що за підтримки керівництва університету вдасться зробити цей вид навчання максимально ефективним та залучити ще більше нових студентів. 